\title{
LANGUAGE, ART, AND THE (SOCIAL) BODY IN MODERN AND POSTMODERN AESTHETICISM: A COMPARISON OF WILDE AND NABOKOV
}

ABSTRACT. In this paper, the author argues for a theoretical difference between the modern and postmodern aestheticism and considers their political implications arguing that modern aestheticism carried progressive or radical political impulse; whereas, under postmodernism, its character shifted into a reactionary politics. The specific political implications that are derived from these two kinds of aestheticism concern the attitude towards human nature, different kinds of narcissistic tendencies and divergent attitudes towards art/culture. Next, the author uses the examples of Oscar Wilde's Picture of Dorian Gray and Nabokov's Lolita to demonstrate how these differences manifest themselves in the works of these two prominent, if not pivotal, artists related to the aesthetic movement in the history of literature. It is concluded that the politics of Oscar Wilde and Vladimir Nabokov differ radically and these differences stem from the fact that their works embody divergent conceptions of aestheticism.

KEYWORDS: aestheticism, modernism, postmodernism, politics, Wilde, Nabokov.

pedjakovacevic90@gmail.com

This paper was submitted on June 30, 2017 and accepted for publication at the meeting of the Editorial Board held on September 29, 2017. 


\section{INTRODUCTION}

When one thinks of aestheticism, the names of Oscar Wilde and Vladimir Nabokov immediately come to mind. However, although they might appear similar in some respects, there are some profound differences between the two of them. This essay is an attempt at illuminating these differences and identifying their roots in the broader philosophical and political outlooks of the two figures. Various ways in which these two writers deal with problems of human nature, art, and narcissism support the claim that Wilde is a typical modern author while Nabokov is a writer who in many respects launches the postmodern movement through his work. Furthermore, two very different political ideologies emerge from these different outlooks as will be shown in the essay.

\section{DEFINING THE TERMS}

\section{MODERNISM}

The final definition of modernism in the arts has never been given particularly due to its many strands and currents. In the philosophical sense, modernity is seen as a belief in progress through rationality and science; it is the reaffirmation of trust in the Enlightenment. When Kant enthusiastically exclaims "Sapere aude" (dare to know; dare to use your own reason), he is asserting his belief that we can know and that we should understand the world and society around us to be able to make the world more like home to us (Kant, 2009). In this sense, the Enlightenment is an optimistic philosophical project asserting that human beings can perfect the imperfect world through the application of their faculty of reason. Foucault (1984, p. 33) writes, "Kant defines [the Enlightenment] in an almost entirely negative way, as an Ausgang, an 'exit', a 'way out". "The exit" that Foucault is referring to is a departure from a millennia-old slumber under beliefs in various sorts of dogmas like religion, patriarchy, tribal mythology, etc.

A century after Kant and the French Revolution with the famous slogan Liberte, Egalite, Fraternite, once the developing European cities failed to produce the kind of improvements in social conditions which were promised by the ideologues of bourgeois 
revolutions, the modern philosophical impulse split into two different currents. The disappointment generated by those failures in combination with conservative political leanings created an antimodern, critical current within the modernist art. Flaubert famously wrote to Turgenev, "I have always tried to live in an ivory tower, but a tide of shit is beating at its walls, threatening to undermine it. It's not a question of politics but of the mental state of France" (Flaubert, n.d.). He does not feel safe in his ivory tower as it is being undermined; however, he blames "mental state of France" for his fate ${ }^{2}$. The other current finds its expression in the idea that one can use the methods of science and rational inquiry to find out why the society failed to address its crucial problems. This is the sort of belief one finds in Karl Marx (Marx, 1992).

\section{POSTMODERNISM}

One plausible way of understanding postmodernism would be to view it as a continuation of the modern project or as the mature stage of that project. We see many authors like James Joyce for example distancing themselves from modernism almost completely by the end of their careers and embracing highly experimental modes of writing characteristic of postmodernism. Another way of looking at postmodernism is to interpret it as a negation of and a reaction to the modern project. Writing an analysis of Kant's famous essay Answering the Question What is the Enlightenment, Foucault is concerned with the possibility of undermining the foundational assumption that human reason and science carry an emancipatory potential and worries that reason can be an exclusionary category that withholds the right of political participation from those who are seen as unreasonable (Foucault, 1984). Furthermore, Herbert Marcuse (1968) defined the modern man as unidimensional because the modern society develops only what he calls the "instrumental reason" or the capacity for science and rationality and neglects everything else as in matters of morality, religion, spirituality, and aesthetics it has nothing to say.

The negation of modernism comes with the events like WWII in which science and technology, namely instrumental reason, caused

2 Attempts to explain periods of crises by appealing to some mysterious categories like "mental states", "cultural decline", etc. have by now established themselves as conservative excuses for non-action and acceptance of status quo. 
destruction of human life without a historical precedent. It also comes with the unmasking of the oppressive character of the modern bureaucratic institutions that were previously seen as agents of social improvement (schools, hospitals, mental asylums, etc.) $)^{3}$. Finally, modernism falls in the eyes of philosophers and artists with the failure of grand emancipatory narratives like communism as the Soviet Union turns into a totalitarian regime. Therefore, postmodernism can be seen as a continuation only of those critical currents of modernism exemplified by Flaubert which are cynical about the human capacity to improve the society and rationalize the world.

As postmodernism becomes the dominant intellectual framework, thinkers who refuse to give up on modern emancipatory projects, usually coming from the Marxist tradition, present a charge against it as a reactionary ideology hiding behind a seemingly progressive mask. Fredric Jameson (1991) notes that the dividing line between modern and postmodern thinkers is found in their understanding of capitalism. Postmodernism sees the old industrial society rift with class struggle as something obsolete in comparison to the new, post-industrial, digital society. Of course, these thinkers are simply mistaking the fact that global capitalism has shifted production towards new geographic areas (India, China, etc.) for its non-existence. Jameson (1991), however, argues that having a position on postmodernism (either defending it or criticizing it) means having the same perspective on global capitalism. David Harvey (1989, p. 328) writes,

"The experience of time and space has changed, the confidence in the association between scientific and moral judgments has collapsed, aesthetics has triumphed over ethics as a prime focus of social and intellectual concern, images dominate narratives, and ephemerality and fragmentation take precedence over eternal truths and unified politics."

In other words, postmodernism no longer believes in the possibility of emancipation, grand emancipatory ideologies and science as a way of improving society; it doubts the existence of absolute truths and emphasizes the aesthetic experience while remaining cynical about the moral questions. For all these reasons, Fredric Jameson (1991) calls postmodernism the "cultural logic of late capitalism". In doing so, he follows Marx and Engels (1976) who argue

3 Here, dystopian writers of 1950 s and 1960s played a crucial role. 
that whatever the dominant ideas of a particular period are, they are the ideas of the ruling class or the ideas that support their rule. If postmodernism is on the whole a dominant belief, it is a reflex of the ideas of the ruling transnational elite in the late capitalist society.

Marx (1992) also predicted that at a certain stage, further development of science and technology under capitalism would no longer be profitable and useful for the owners of the means of production. Consequently, capitalism would seek to hinder scientific breakthroughs while the humanities as the last residue of social criticism would be infiltrated by ideology from the inside and publicly defamed from the outside ${ }^{4}$. Postmodernism then serves both functions as a way of obscuring the discourse and frustrating the development of the humanities while providing a fertile soil for a conservative attack on the humanities as disciplines that are destroying the youth's sense of high art instead of fostering it (see Bloom 2012) 5 .

\section{AESTHETICISM}

Aestheticism is an attempt to bring the notions of the good and the beautiful together (Lambourne, 1996). Since the dawn of Western philosophy, aesthetics, philosophy of the beautiful, and ethics, philosophy of the good, were regarded as different disciplines. Aristotle writes about them in separate books and most philosophers discuss them completely independently. Even as late as in the work of Kant, ethics and aesthetics appear in different books by the same author. In the Victorian era, the famous art theoretician,

4 David Graeber argues that around 1970, scientific and technological forces developed under capitalism outgrew the capitalist mode of production which is why from then on we are seeing a decline in productivity of scientific research and witnessing a widespread disappointment in the achievements of science in the last decades - there is still no cure for cancer, no free solar energy, space exploration is slowing down, there are no private flying cars, etc. The thesis is that existing economic relations are inadequate to accommodate those discoveries as they would present a threat to them (Graeber 2017).

5 Also see Steven Pinker's (2002) book Blank Slate, especially the chapter on literary criticism, for an account of the decline of the humanities under postmodern assumptions that correlated with the reversal of the social status of a literary critic from the status of a respected public intellectual to essentially "a joke". This shift in the status of the humanities correlates strongly with the shift from modernism to postmodernism. 
Walter Pater, embarked on a project of fusing these two concepts into one (Lambourne 1996). This idea initiates what can be seen as a quite broad current of artists and thinkers who can be regarded as aestheticists. Here, however, the author will argue that within the aesthetic movement one has to differentiate between modernist and postmodernist aestheticism. The modernist version will here be identified with Wilde and the postmodern one will be illustrated by Nabokov. Further, the author will argue that the modernist aestheticism is politically leftwing while, under postmodernism, it takes on a reactionary form.

In the analysis of aestheticism as having two branches, it is useful to recall Derrida's insight about the existence of ideologically charged hierarchies within every binary (Derrida \& Spivak 1997). Aestheticism is a movement that draws morality and beauty together (Lambourne 1996). Therefore, it forms a binary, morality/ art, relying on another ancient binary, life/art, or the philosophical question of whether art imitates life or life imitates $\operatorname{art}^{6}$. The author would argue that modernist aestheticism as represented by Wilde emphasizes the side of morality and proposes that beautiful art is one that, when imitated by life, can produce beautiful life ${ }^{7}$. Nabokov's writings give rise to a completely different view which is that one should live a life that, when copied, can produce beautiful art. Before illustrating the above claim with evidence from the texts of Lolita and The Picture of Dorian Gray, it is noteworthy to mention that the argument could be supported by reference to biographical information as well as other texts written by these authors but

6 One should recall that Marx's primary charge against rightwing Hegelianism was focused on the idea that independent development of ideas (i.e. art and culture) translates itself in the lives of people in the sense that life imitates art or culture. According to Lenin's (1992) reading of Marx, art and culture imitate life as they emerge from the dominant material relationships. It is the task of the proletariat to overthrow the bourgeois state and transform the socioeconomic relationships in order to create conditions out of which a progressive culture could emerge.

7 Note that the approach which we attribute to Wilde is not a purely materialist one as it does not rely only on intervention into material social conditions as a precondition for creation of truly beautiful art. Rather, we would argue that Wilde takes Gramsci's (1991) approach whereby life and art are understood as being in dialectical relationship where they both influence one another at the same time. This dialectical wheel can be spun in both progressive and reactionary direction from every side. The goal of the progressive artist is to give a progressive spin to it from the artistic side. 
doing so goes beyond the scope of this work (see Rorty 1989 and Eagleton 2011).

\section{HUMBERT AND DORIAN: TWO SIDES OF THE COIN OF AESTHETICISM}

In this section, we will put forward an argument that, for Wilde, art's main goal is to be beautiful, but an implication of his view is that beautiful art is one that, once reflected in or imitated by life, makes life beautiful as well. Nabokov is completely disinterested in the idea of art's influence on life. This contrast can be further explained by using the philosophical distinction between a cause and a purpose. According to Wilde's view of aestheticism, art is what gives rise to cultural and social norms and an artist has to create beautiful art that would in turn create beautiful life. Nabokov takes the opposite view, which is that art is the purpose of life and one lives merely to collect material for beautiful art. The following contrasts will illustrate this fundamental distinction between Nabokov and Wilde.

\section{VIEWS ON HUMAN NATURE}

The first relevant distinction between these two novels regards the issue of the sources of evil in the human psyche. Wilde's answer is quite straightforward. He believes that evil is an external influence as evidenced in the Picture of Dorian Gray. There are two external sources that corrupt Dorian - art and society. Lord Henry is the main source of corruption for Dorian Gray. For example, the following quote illustrates Lord Henry's active role in Dorian's transformation, "That curiosity about life which Lord Henry had first stirred in him, as they sat together in the garden of their friend, seemed to increase with gratification" (Wilde, 1993, p. 115). Lord Henry is the one who "stirs" the insatiable and corruptive curiosity about life in Dorian. There is also evidence in the text that Wilde ultimately views the society as the source of moral decline. Wilde (1993, p. 114) describes the society's relationship towards Dorian in the following way,

"There was something in the purity of his face that rebuked them. His mere presence seemed to recall to them the memory of the innocence that they had tarnished. They wondered how one so charming and graceful as he was could have escaped the stain of an age that was at once sordid and sensual." 
Clearly, upon seeing Dorian, others are puzzled as to how he could have resisted the temptations of the times.

Nabokov, on the other hand, places evil at the heart of human psyche. We will identify several instances to support the claim that Humbert comes across as a purely evil character. Consider the following thought, "She had very vulnerable legs, and I decided I would limit myself to hurting her very horribly as soon as we were alone" (Nabokov, 1992, p. 18). Humbert is always conscious of the ways in which he can hurt other people so that they suffer as much as possible. It should be added that he is referring to his former spouse in this quote. There is another very similar example also concerning his first wife: "In the good old days, by merely twisting fat Valechka's brittle wrist (the one she had fallen upon from a bicycle) I could make her change her mind instantly; but anything of the sort in regard to Charlotte was unthinkable" (Nabokov, 1992, p. 58). These two examples illustrate what Terry Eagleton (2010) calls "evil for the sake of evil" or evil in its purest form.

In most other cases, Humbert has some other goal in mind when he commits an evil act, but his relationship towards his first wife is deeply sadistic and perverted. Other similar cases can be found when Humbert contemplates persuading Charlotte into letting him sleep with Lolita in front of her by threatening to leave her (Nabokov, 1992, p. 50); or when he considers impregnating Charlotte just so he could drug Lolita and rape her while Charlotte is recovering from complications following the Cesarean procedure (Nabokov, 1992, p. 56). This latter example is also very indicative because he imagines a hypothetical birth of his child and what he would wish in that situation is for the mother to go through severe complications so he could rape a teenager.

The interpretation of Lolita as a novel about cruelty (or evil) has been suggested by several important critics. Martin Amis (2013) has identified this theme as being central to the novel. However, Rorty's (1989, p. xvi) insight is perhaps closer to the present discussion because he claims that Nabokov is trying to make the reader identify with one extremely cruel character, "Fiction like that of Choderlos de Laclos, Henry James, or Nabokov gives us the details about what sorts of cruelty we ourselves are capable of". By making this claim, Rorty (1989) does not mean to include the instances of outright sadism that Humbert exhibits but rather his general obliviousness about the fact that he is hurting Lolita. We would argue 
that this move on the part of Nabokov is central to his view of evil as being an inherent part of human nature.

The difference as to where evil is located can also be tied back to the political views, which once again illustrates the political differences between modernism and postmodernism. The modern position that sees negative influences as coming from the society is essentially connected to Romanticism and Rousseau's idea of the "Noble Savage" and that view seems to prevail in the leftist thought. On the other hand, one need not mention more than the classical rightwing argument about human nature and people being inherently greedy and selfish that is used to discredit leftist ideas and justify futility of social intervention. The view of evil as inherent to humans pervades the postmodern culture from serialkiller horror movies to black and white worlds of soap operas.

\section{Two KINDS OF NARCISSISM}

Two different interpretations of aestheticism that we are arguing for here can be identified in the work of Wilde and Nabokov with respect to the way in which they deal with the idea of narcissism and different versions of narcissism that the protagonists exhibit. It can be shown how modern narcissism is reality-based, which means that it is aimed towards objective physical beauty, with which one never fully identifies. On the other hand, postmodern narcissism is a subjective fetishist conviction that one is physically attractive independently of the objective reality. Before demonstrating this profound difference as it manifests itself on Dorian and Humbert, the author will substantiate the claim that subjective narcissism is postmodern while the objective one is modern with some general observations about the cultures of the two periods. One general observation can be that the early modern period can be seen as a culture of the mirror while the postmodern one can be labeled as the culture of Photoshop.

Under the modern framework the human being became the subject of its own analysis both in terms of scientific explanations and in terms of humanistic pursuits. Humans became obsessed with self-analysis and the metaphor of the mirror can capture this tendency very powerfully. From large elaborate Victorian mirrors that became obligatory items in every bourgeois household, to the doppelganger theme in the early modern literature and realism in the arts more generally, mirror in the symbolic sense can be taken 
to be at the center of much of that culture. This kind of narcissism is rather similar to its classical interpretation in the original myth of Narcissus whose main problem seems to be that he cannot convince himself that he is indeed as beautiful as the reflection suggests. Therefore, he cannot break away from the constant objective feedback that demonstrates his beauty over and over again.

Dorian, therefore, seems to be a narcissist of the classical type. Like the mythic Narcissus, Dorian spends a lot of time in front of the mirror. Here is only one passage from the text that illustrates this,

"Often, on returning home from one of those mysterious and prolonged absences ... he himself would creep upstairs to the locked room, open the door with the key that never left him now, and stand, with a mirror, in front of the portrait that Basil Hallward had painted of him, looking now at the evil and aging face on the canvas, and now at the fair young face that laughed back at him from the polished glass." (Wilde, 1993, p. 114).

This image of Dorian in front of the mirror and his portrait is among the first associations that people have when the book is mentioned. Furthermore, there should be little doubt that he is truly a very handsome man. Indeed, the narrator that describes his beauty is omniscient and reliable so there is no reason to doubt the idea that his narcissism is based on objective facts.

Turning now to Nabokov's novel and the character of Humbert, one can characterize him as a completely different kind of narcissist. Under postmodernism, beauty and narcissism are no longer reality-based. Since beauty is the final purpose of life, people feel a compulsive need to be beautiful. Above, we dubbed that kind of culture the culture of Photoshop because computer software is now used on virtually every photo and people spend hours polishing their photos trying to convince themselves and others that they are much more beautiful than they really are. This tendency is apparent on the social networks as well where life is subordinated to making beautiful pictures of oneself and sharing them with others. Also, one can even argue that sex symbols of today are precisely those who (for class or whatever reasons) are able to best convince themselves that they indeed are beautiful ${ }^{8}$.

Humbert is one of the earliest embodiments of this cultural tendency. First, the narrator who tells us about Humbert's physical attractiveness is clearly unreliable - he writes post festum which means that there is a significant temporal distance from the events 
of the story and he does not remember many details (Marković, 2011). Even more importantly, it is Humbert himself who tells us about his own beauty because it is him who is narrating the story. When he describes himself as handsome or rather claims he is handsome, the reader has the impression that he never actually doubted that proposition. There are numerous passages that illustrate this. In many cases, he simply states that he is extremely handsome without feeling the need to justify that claim. It almost seems like he believes that he is handsome by definition and the claim about his beauty needs about as much support as the claim that a circle is round. ?he following quotation illustrates this quite well, "A little money that had come my way after my father's death ... in addition to my striking if somewhat brutal good looks, allowed me to enter upon my quest with equanimity" (Nabokov, 1992, p. 7). Humbert explains to the reader where he got his money from but his "good looks" are simply asserted without further explanation. The same is true in the following self-characterization - "Despite my manly looks, I am horribly timid" (Nabokov, 1992, p. 36). In some instances, we do get some statements in the way of description of his physical appearance like in the following sentence, "I have all the characteristics which, according to writers on the sex interests of children, start the responses stirring in a little girl: clean-cut jaw, muscular hand, deep sonorous voice, broad shoulder" (Nabokov, 1992, p. 28). However, this description of male attractiveness is so stereotypical that it seems as though it were copied from a biology textbook. This description definitely reminds one of retouching one's photo in Photoshop because when doing so people usually rely on what is generally known to be attractive and try to emulate that in their photos as much as possible.

We would argue that in this sense, Humbert's narcissism is radically different from Dorian's and that this difference reflects the deeper split between modern and postmodern aestheticism(s). Under postmodernism, aesthetics has risen above ethics to the point of becoming the very purpose of life itself and the meaning of life has become equated with being beautiful. Hence, one can

8 The culture of fitness and plastic surgery as ways of improving one's physical appearance are still modern tendencies, the author would argue, because they at least make an attempt at substantiating one's narcissism with some objective basis, and indeed, science has a lot to do with both of these tendencies. For postmodern narcissists, this objective basis is completely redundant because they can use software to improve their photos as much as they want. 
explain the incredible mania around physical beauty and many cultural phenomena outlined above in light of the thesis that this subjective narcissism has become one of the dominant characteristics of our time.

With respect to the notion of postmodern narcissism introduced in this section, an anonymous reviewer brings up the phenomenon often referred to using the phrase "ugly is the new beautiful". In the recent years, the global culture has witnessed a number of phenomena in the realm of aesthetic experience that pose a radical challenge to the traditional concept of beauty as such. This trend has been observed both by the general population and by art critics. For instance, Scruton (2009) identifies modern architects, visual artists like Damien Hirst and fashion designers as typical examples of this recent trend of sheer ugliness posing as high art. Scruton (2009) argues that the responsibility for the rise of ugly art lies with pampered elite artists educated in the heights of the academic ivory tower and sponsored by patrons who are profoundly alienated from the rest of the population. We would argue that this trend is an intensification of Humbert's logic in the sense that artists can use their elite status to define and reshape the meaning of aesthetic experience. Apparently, it is no longer sufficient to insist on the aesthetic value of something that is clearly not beautiful, which is what Humbert was doing. Some elite artists are now taking a step further in brazenly ascribing the property of beauty to objects that are clearly ugly.

\section{THE RELATIONSHIP TOWARDS THE ART}

One can easily pursue the proposed contrast between Humbert and Dorian further by analyzing their relationship towards the arts and the way in which that relationship affects their lives. Namely, in light of the claim that Humbert is a typical postmodern, selfabsorbed, egoistic narcissist, and Dorian is a modern, insecure, impressionable objective narcissist, one can make a rather straightforward prediction about what their relationship towards the arts would be. Namely, since Humbert is a self-absorbed and egoistic postmodern character, one would predict that he would be more inclined towards writing than towards reading and prefer producing art rather than consuming it. In contrast, Dorian would be expected to prefer reading and enjoying artworks instead of 
creating them. This prediction seems to be completely borne out by the textual evidence from the two novels.

When one thinks about the early modern attitudes towards art, one immediately thinks of the birth of cheaply available printing press and the effects it had on the rise of mass culture. However, the period of $19^{\text {th }}$ and early $20^{\text {th }}$ century was marked by an enormous public interest in literature. Classics were actually very popular books at the time. Dickens, Thackeray, George Eliot and others had massive readerships and their books appeared in monthly instalments causing a kind of public hysteria similar to the one seen when sequels of famous blockbusters appear today. Book reading was a ubiquitous phenomenon at the time, and an ordinary person read hundreds of novels during their lifetime. Therefore, the early modern culture was definitely a culture of readership and the attitude towards the arts was mostly receptive.

Dorian's attitude towards art is precisely of this sort. Dorian is an avid reader and art lover. What is more, there are short episodes in the novel when Dorian is going through a real reading frenzy. At the end of chapter ten, the reader sees Dorian being literally absorbed by the book that Henry gives him. Later, in chapter eleven, he first orders the first edition of the book in various colors and afterwards becomes a passionate art collector, acquiring and enjoying all sorts of different artworks.

Nabokov's hero is the exact opposite of that. One mostly thinks of Humbert as a writer not as a reader. The text that the reader is exposed to is written by Humbert himself based on the diary that he kept meticulously over many years. One should notice that there

9 An anonymous reviewer suggests qualifying this statement and giving it a class perspective. We agree with the reviewer that it is a received view that readership was quite widespread in the $19^{\text {th }}$ century but only in middle class circles since members of the working class were mostly illiterate. It would not hurt the argument presented here to qualify this statement in the way reviewer proposes. In that case, the claim would be that in the $19^{\text {th }}$ century, literate people were immersed in literature far more than they are today. However, recent work by Rose (2010) presents us with a completely forgotten and sometimes actively suppressed picture of the lively intellectual life of the British working class in the $19^{\text {th }}$ century. The book is filled with written testimonies of working class communities teaching themselves how to read in order to access the works of Homer or Shakespeare and their contemporaries like Dickens, Thackeray or even Marx. Many artisans would pay young boys to read to them while they work while young people would meet every evening after work to read together and discuss the latest intellectual developments. 
is no actual purpose to his writing throughout that time. He is mostly writing just for the sake of it. Furthermore, his piece of literary criticism titled "The Proustian theme in a letter from Keats to Benjamin Bailey" was chuckled over by the six or seven scholars who read it" (Nabokov, 1992, p. 8). The number of people who read the paper is clearly given purposefully to illustrate the size of the audience which Humbert addresses. Even stronger examples are his Manuel of French Literature and "Histoire abrégée de la poésie anglaise", which are both enormously long works that took him about a decade to write and neither of which was ever published (Nabokov, 1992, p. 8). Throughout the book, Humbert is constantly writing, sometimes for more than fifteen hours a day, and yet no one reads his writing.

Humber's productive attitude towards art is the polar opposite of Dorian's receptive one. However, the question is whether this difference fits into the modern/postmodern distinction which is being outlined here. Thinking of postmodern culture, it really is profoundly different from the modern one as the reading mania seems to have completely disappeared. People are receiving information, perhaps more than ever, but the idea of reading as such has become obsolete. Whereas in the late $19^{\text {th }}$ century, at least the majority of middle-class children in England would have read all Dickens' novels and many others by the time they finish school, today, the idea of reading at least one novel of that length is something that even students of English Literature find tedious. On the other hand, there is clearly an emerging mania for writing. It is not just about personal diaries or journals that were popular in 1960s and 70s. Today, blogs have become one of the central cultural institutions. The problem, however, is that virtually no one reads other people's blogs. There is a saying in the blogosphere that "never in the human history have so many people been writing so many things no one read". The ubiquity of writing has gone so far that it is not an exaggeration to say that many people now write more pages of text during their lifetime than they actually read and most of what they write is autotelic, in other words, is done for its own sake ${ }^{10}$.

The political dimension of this distinction is also very important. One could read this contrast in terms of the famous debate between Adorno and Benjamin where Adorno saw emancipatory potential in high culture (Adorno \& al. 2002) while Benjamin (2010) argued that immersion in popular culture is the only way to break with the 
bourgeois/aristocratic burden of high culture ${ }^{11}$. Even though Humbert is engaged in writing most of the time, he is quite clearly immersed in high art, which would make him a good testing ground for Adorno's hypothesis. He is trained in English literature and since he has written so much on English and French classics, presumably he has also read many of them. Meanwhile, he lives an isolated solitary life, which corresponds to the stereotypical representation of the lovers of classical literature today. The kind of life that he leads is rather dehumanized and is certainly far from any kind of progressive political activity. For those reasons, I would argue that Humbert as a kind of "test case" undermines Adorno's prediction.

Concerning the way in which Dorian Gray fits Benjamin's prescription is less clear, but we think it can be seen that way. It seems that what Wilde has in mind when writing The Picture of Dorian Gray is something like Benjamin's conception of the relationship between art and politics; however, he is trying to imagine what happens when one is exposed to bad popular culture. Benjamin did predict that the political effects of immersion into pop culture or low culture would depend crucially on the political character of the particular kind of pop culture one is engaged in (Benjamin, 2010). It is in this sense that Benjamin believes that one should be deeply concerned about the political character of the art one is creating and the question of what kind of society would a work of art produce if replicated by people should always be asked. The kind of artistic production that is expected from an ordinary individual on this view is merely to make one's life a work of art. Benjamin's prescription is not for everyone to try to produce some kind of art in the narrow sense falsely believing that everyone is a talented artist. Instead, Benjamin believes that one should expose oneself to the right kind of lively, progressive, popular culture and simply try to recreate it in one's own life.

10 It is necessary to draw a sharp distinction here between this phenomenon of writing for its own sake and another contemporary phenomenon, which could be considered progressive, the concept of collective writing and fan fiction. The reason why this latter tendency is progressive is because it gives rise to dynamic collectives of individuals with similar interests where writing among other things creates the sense of community and horizontality as opposed to the hierarchic and passive experience of reading.

11 One can trace the origins of theoretical positions of postmodernism precisely to this debate when Adorno and Horkheimer start to undermine the very concept of the Enlightenment (Adorno \& al). 
Dorian seems to be a perfect piece of negative evidence that Benjamin is correct. Unlike Humbert, Dorian does not waste much time on unsuccessful attempts at artistic or intellectual creation. Instead, he is letting the arts that influence him play out in the kind of life that he lives. The reader gets a succinct formulation of this principle that Dorian follows in the following sentence from the novel, "and, certainly, to him life itself was the first, the greatest, of the arts, and for it all the other arts seemed to be but a preparation" (Wilde, 1993, p. 115). The result is that Dorian is living a very active and engaged life, which is in sharp contrast with that of Humbert. Nonetheless, the kind of life that he is living unfortunately turns into a complete moral disaster. This could be explained by the fact that Dorian is "poisoned" by a very bad piece of popular culture. Indeed, it seems that Wilde is doing his best to emphasize how bad this book really is in the following sentence,

"It was a novel without a plot and with only one character, being, indeed, simply a psychological study of a certain young Parisian who spent his life trying to realize in the nineteenth century all the passions and modes of thought that belonged to every century except his own, and to sum up, as it were, in himself the various moods through which the world-spirit had ever passed" (Wilde, 1993, p. 112).

In other words, this obscure young Parisian is trying to fuse all sorts of different cultures that he does not really understand as none of them is his own, into a one-character novel. Although we might risk pushing the argument too far, we will state that this one-sentence description of the corruptive art about which Wilde wants to warn us sounds painfully like a prophetic sketch of the postmodern art. This novel that Wilde describes has all the features of a standard postmodern technique called pastiche. In addition, this desire to "realize ... all the passions and modes of thought that belonged to every century except his own" sounds alarmingly like Jameson's (1991) statement that postmodernism engages into "random cannibalization of all the styles of the past". Precisely for that reason, postmodernism has no distinct style of its own, and so the postmodernist artist cannot "realize ... the passions and modes of thought" of his own time.

Wilde's other clue about the kind of art that Dorian exposed himself to is Dorian's portrait. One reason why Wilde is introducing this mysterious equivalence between Dorian's moral character and a painting, which is a work of art, is quite possibly to stress the fact 
that in our lives we are reproducing the kind of art we are exposing ourselves to. In Dorian's case, since the painting becomes gruesome, the reader is informed that the literature that he read was gruesome as well. The Picture of Dorian Gray is then a warning about the impact that bad or in Benjamin's terms ideologically reactionary culture can have on our lives. Again, Wilde's aestheticism then erects an ethical standard of evaluation for a work of art. According to this ethical standard, in order to determine whether a novel or any piece of art is beautiful, one needs to ask whether it would produce a beautiful life if put into practice.

CONCLUSION In conclusion, despite the fact that they both belong to the artistic movement called aestheticism, Nabokov and Wilde are profoundly different writers. While Nabokov's writing is an example of postmodern art, Wilde's work is clearly modernist at its core. Differences in the ways in which these two writers treat narcissism, human nature, the relationship between life and art, etc. are truly profound and all of those differences can be explained by adopting the idea that there is a postmodernist and a modernist version of aestheticism. Like postmodernism generally, postmodernist aestheticism is politically conservative and the reverse is true for the modernist version of the same movement. Based on these insights, we believe that artistic creation should not give up on modernist tenets and it should reaffirm its status as a mode of critical reflection on the society rather than being a self-absorbed, completely autotelic institution that it has become under postmodernism.

Adorno, T. W., Noerr, G. S., \& Horkheimer, M. (2002). Dialectic of Enlightenment. Stanford: Stanford University Press.

Amis, M. (2013, December 28). Lolita: Martin Amis on Morality in Vladimir Nabokov's Novel (1998). Retrieved June 15, 2017, from http://www.youtube.com/watch?v=QiG_QK1vvUU

Benjamin, W. (2010). The work of art in the age of mechanical reproduction. Lexington, KY: Prism Key Press.

Bloom, A. D. (2012). The closing of the American mind. New York: Simon and Schuster Paperbacks.

Derrida, J., \& Spivak, G. C. (1997). Of grammatology. Baltimore: Johns Hopkins University Press. 
Eagleton, T. (2010). On Evil. New Haven: Yale University Press.

Eagleton, T. (2011). Why Marx was right. New Haven, CT: Yale University Press.

Flaubert, G. (n.d.). Gustave Flaubert Writes Letter to Ivan Turgenev. Retrieved June 15, 2017, from http://www.rjgeib.com/about-me/faq/gustave-flaubert.html

Foucault, M. (1984). What is Enlightenment? In: P. Rabinow (Ed.), The Foucault Reader (pp. 32-50). New York: Pantheon Books.

Graeber, D. (2017, May 10). Of Flying Cars and the Declining Rate of Profit. Retrieved June 15, 2017, from http://www.thebaffler.com/salvos/of-flyingcars-and-the-declining-rate-of-profit

Gramsci, A. (1991). Prison Notebooks. New York: Columbia University Press.

Harvey, D. (1989). The Condition of Postmodernity. Oxford: Blackwell.

Jameson, F. (1991). Postmodernism, or, the cultural logic of late capitalism. London: Verso.

Kant, I. (2009). An Answer to the Question What is Enlightenment. New York: Penguin.

Lambourne, L. (1996). The Aesthetic Movement. London: Phaidon.

Lenin, V. I. (1992). The State and Revolution: the Marxist Theory of the State and Tasks of the Proletariat in the Revolution. London: Penguin Books Limited.

Marcuse, H. (1968). One Dimensional Man. London: Sphere Books.

Marković, V. (2011). Uporedni svetovi. Belgrade: Stubovi Kulture.

Marx, K. (1992). Manifesto of the communist party. Raleigh, N.C.: Alex Catalogue.

Marx, K., \& Engels, F. (1976). The German ideology. Moscow: Progress .

Nabokov, V. (1992). Lolita. New York: Knopf.

Pinker, S. (2002). The Blank Slate: the Modern Denial of Human Nature. New York: Viking.

Rose, J. (2010). The intellectual life of the British working classes. New Haven: Yale University Press.

Rorty, R. (1989). Contingency, irony, and solidarity. Cambridge: Cambridge University Press.

Scruton, R. (2009, December 2). The Modern Cult of Ugliness. Retrieved September 1, 2017, from http://www.dailymail.co.uk/debate/article-1231948/ Why-sordid-art-like-Tracey-Emins-led-cult-ugliness-Britain.html

Wilde, O. (1993). The picture of Dorian Gray. Charlottesville, Va.: University of Virginia Library. 
ПРЕДРАГ С. КОВАЧЕВИЋ

УНИВЕРЗИТЕТ У НОВОМ САДУ

ФИЛОЗОФСКИ ФАКУЛТЕТ

ОДСЕК ЗА АНГЛИСТИКУ

РЕЗИМЕ

ЈЕЗИК, УМЕТНОСТ И (ДРУШТВЕНО) ТЕЛО У МОДЕРНОМ

И ПОСТМОДЕРНОМ ЕСТЕТИЗМУ: ПОРЕЪЕЊЕ ВАЈЛДА И НАБОКОВА

У овом раду износимо аргумент за теоријску разлику између модерног и постмодерног естетизма и разматрамо њихове политичке импликације тврдећи да модерни естетизам садржи прогресивне или радикалне тенденције, док се под постмодернизмом његов садржај померио ка реакционарној политици. Појединачне политичке импликације које изводимо из ове две врсте естетизма тичу се става о људској природи, различитим врстама нарцистичких тенденција и супротстављених ставова о уметности и култури. Даље, користимо примере из Вајлдове Слике Доријана Греја и Набоковљеве Лолитее како би илустровали појавне облике ових разлика у делима ове двојице писаца који представљају кључне фигуре естетизма. Закључујемо да су политички ставови Вајлда и Набокова радикално супротстављени и да ове разлике потичу из чињенице да њихова дела отеловљују супротстављене концепте естетизма.

Кључне речи: естетизам, модернизам, постмодернизам, политика, Вајлд, Набоков.

Овај чланак је објављен и дистрибуира се под лиценцом Creative Commons

Ауторство-Некомерцијално Међународна 4.0 (CC BY-NC 4.0 |

https://creativecommons.org/licenses/by-nc/4.0/).

This paper is published and distributed under the terms and conditions of the Creative Commons Attribution-NonCommercial International 4.0 licence (CC BY-NC 4.0 | https://creativecommons.org/licenses/by-nc/4.0/). 